\begin{tabular}{cc}
\hline The Open Bioactive Compounds \\
Journal \\
CrossMark \\
Content list available at: www.benthamopen.com/TOBCJ/ \\
DOI: $10.2174 / 1874847301705010001$
\end{tabular}

RESEARCH ARTICLE

\title{
Cytotoxic Activity of Two Cembranoid Diterpenes from Nicotiana Sylvestris Against Three Human Cancer Cell Lines
}

\author{
Amir Reza Jassbi ${ }^{1, *}$, Marzieh Vafapour ${ }^{2}$, Ardeshir Shokrollahi ${ }^{2}$, Omidreza Firuzi ${ }^{1}$, Mehdi Zare ${ }^{1}$, \\ Jima N. Chandran ${ }^{3}$, Bernd Schneider ${ }^{3}$ and Ian T. Baldwin ${ }^{4}$ \\ ${ }^{I}$ Medicinal and Natural Products Chemistry Research Center, Shiraz University of Medical Sciences, Shiraz, Iran \\ ${ }^{2}$ Department of Phytochemistry, Yasouj university, Yasouj 75914-353, Iran \\ ${ }^{3}$ Research group Biosynthesis/NMR, Max Planck Institute for Chemical Ecology, Jena, Germany \\ ${ }^{4}$ Department of Molecular Ecology, Max Planck Institute for Chemical Ecology, Hans-Knöll-Strasse 8, D-07745 Jena, \\ Germany
}

Received: May 23, 2017

Revised: August 29, 2017

Accepted: September 01, 2017

\section{Abstract:}

\section{Background:}

Two cembranoid diterpenes, [( $1 S, 2 E, 4 R, 6 R, 7 E, 11 E)-2,7,11$-cembratriene-4, 6-diol] (1) and its epimer [(1S, 2E, 4S, $6 R, 7 E, 11 E)-2,7,11$-cembratriene-4, 6-diol] (2) were isolated from surface dichloromethane washings and chloroform extract of Nicotiana sylvestris leaves.

\section{Methods:}

The compounds were purified using silica gel column- thin layer- and flash column chromatography methods. The structures of the isolated compounds were elucidated using spectroscopic analysis and their ${ }^{1} \mathrm{H}$ and ${ }^{13} \mathrm{C}$ NMR spectroscopic data were compared with those of authentic samples reported in the literature. The cytotoxic activity of $\mathbf{1}$ and $\mathbf{2}$ against three human cancer cell lines, including LS180 (human colon adenocarcinoma), MCF-7 (human breast adenocarcinoma) and MOLT-4 (human lymphoblastic leukemia) were evaluated using 3-(4,5-dimethylthiazol-2-yl)-2,5-diphenyltetrazolium bromide (MTT) colorimetric bioassay.

\section{Results:}

The $\mathrm{IC}_{50}$ values of compounds 1 and 2 were calculated to be between $(28.4 \pm 3.7$ up to $44.0 \pm 6.4 \mu \mathrm{M})$ (mean \pm S.E.M.) for the above mentioned cell lines.

Keywords: Nicotiana sylvestris, Solanaceae, Cembranoid diterpenoids, Anticancer agents, Acyclic diterpenoids, Sesquiterpenoids.

\section{INTRODUCTION}

Nicotiana sylvestris Spegazzini \& Comes is a Solanaceae, known by the common names South American tobacco, woodland or flowering tobacco. N. sylvestris is a perennial plant, indigenous to northwestern Argentina. This plant is considered to be one of the ancestors of Nicotiana tabacum [1].

The two cembranoid diterpenes, [(1S,2E,4R,6R,7E,11E)-2,7,11-cembratriene-4,6-diol] (1) and its C-4 epimer, [(1S,2E,4S,6R,7E,11E)-2,7,11-cembratriene-4,6-diol] (2) together with acyclic diterpenoids, 17-hydroxygeranyllinalool and two sesquiterpenoids were isolated from the leaves wax of $N$. sylvestris [2].

\footnotetext{
* Address correspondence $>$ to this author at the Medicinal and Natural Products Chemistry Research Center, Shahid Abaeiyan Ave, Zip: 71348-53734, Shiraz, Iran, Tel: +98-071-32303872, Fax: +98-071-32332225; E-mails: arjassbi@hotmail.com, jassbiar@sums.ac.ir
} 
The cembranoids 1 and its C-4 epimer (2) are two major constituents of different tobacco species [3]. They are thought to function as insecticides and as inhibitors of plant-growth and fungal-spores germination [4, 5]. Additionally, they are reported as aldose reductase and prostaglandin inhibitors. They inhibited behavioral sensitization to nicotine in rats and blocked several types of nicotine acetylcholine receptors [6, 7]. Compounds $\mathbf{1}, \mathbf{2}$ and their semisynthetic derivatives, which were transformed by catalytic action of terrestrial and marine bacteria or via chemical transformation, have been reported as anticancer agents by different authors in animal and in vitro models against human cancer cells [8 - 11]. However, to the best of our knowledge, their activity against LS180 (human colon adenocarcinoma), MCF-7 (human breast adenocarcinoma) and MOLT-4 (human lymphoblast leukemia) is discussed here for the first time.

\section{MATERIALS AND METHODS}

\subsection{General Experimental Procedures}

Optical rotations were measured by a Kruss Optronic polarimeter in chloroform. IR spectra were recorded on a Perkin Elmer Spectrum One FT-IR spectrometer. The ${ }^{1} \mathrm{H}$ and ${ }^{13} \mathrm{C}$ NMR spectra were recorded by Bruker Avance 400 and 500 spectrometer $\left({ }^{1} \mathrm{H}: 400\right.$ and $500 \mathrm{MHz},{ }^{13} \mathrm{C}$ : 100 and $\left.125 \mathrm{MHz}\right)$ using $\mathrm{CDCl}_{3}$ as solvent and TMS as the internal standard. Mass spectra were recorded on an Agilent $5975 \mathrm{C}$ inert GC/MSD. TLC analyses were performed on pre coated silica gel $60 \mathrm{~F}_{254} 0.5 \mathrm{~mm}$. The TLC plates were impregnated with 5\% $\mathrm{AgNO}_{3}$. The silica gel (230-400 mesh) impregnated with silver nitrate was used as the stationary phase for flash column chromatography (FCC) and silica gel (70-230 mesh) for the gravity column chromatography (CC).

Fetal bovine serum (FBS), phosphate buffered saline (PBS), RPMI 1640 and trypsin was purchased from Biosera (Ringmer, UK). Hexane, ethyl acetate, methanol, dichloromethane, dimethyl sulfoxide, silica gel for CC and FCC, the TLC plates and silver nitrate were purchased from Merck (Darmstadt, Germany). 3-(4,5-dimethylthiazol-2-yl)-2,5diphenyltetrazolium bromide (MTT) were obtained from Sigma-Aldrich (St. Louis, MO, USA). Cisplatin was purchased from EBEWE Pharma (Unterach, Netherlands), penicillin/streptomycin were purchased from Invitrogen (San Diego, CA, USA).

\subsection{Plant Material and Extraction}

The seeds of N. sylvestris were obtained from Max Planck Institute for Chemical Ecology (MPICE's) glass house and cultivated in the greenhouse of Medicinal and Natural Products Chemistry Research Center (MNCRC) in December 2012. The cultivation procedure was the same as previously reported [12]. Briefly, about 20 seeds after sterilization were germinated on phytagel agar and kept in a growth chamber with 16/8 h day and night, the day and night temperature was set at 30 and $20 \pm 1^{\circ} \mathrm{C}$ respectively. After $10 \mathrm{~d}$, the seedlings were transferred to soil and transferred to glasshouse with the same light and temperature regimes and irrigations once a day. After $34 \mathrm{~d}$, the plants were harvested and their leaves were subjected to extraction.

At room temperature, the leaves of the plants $(136.0 \mathrm{~g})$ were placed in DCM $(200 \mathrm{~mL})$ for 30 seconds. Then, the surface-extracted leaves were subjected to chloroform extraction for three days. The extracts were concentrated in vacuum at $40^{\circ} \mathrm{C}$. The two extracts were subjected to silica gel TLC analyses and after assuring their similarity, were pooled (2.6 g). $\mathrm{AgNO}_{3}$ (3\%)-impregnated silica gel (230-400 mesh, $100 \mathrm{~g}$ ) was used for purification of the extract's constituents. Elution of the column started with $n$-hexane, continued with stepwise increasing the EtOAc portion up to $100 \%$ to increase the polarity of the eluent mixture, and ended up with 5\% MeOH in EtOAc. Fractions $18-21$, each 75 $\mathrm{mL}$, were checked with $5 \% \mathrm{AgNO}_{3}$ impregnated silica gel- TLC and found to be of a similar composition. Similar fractions were pooled $(437 \mathrm{mg})$. Then flash chromatography was employed (column dimensions: $202 \mathrm{~cm}, 15 \mathrm{~g}$ silica gel, $n$-hexane-EtOAc solvent system) to obtain compound $\mathbf{1}(78 \mathrm{mg})$ as a pure gummy material. Compound 2 (34.0 $\mathrm{mg})$ was obtained from fraction 22 by flash chromatography (silica gel (230-400 mesh, $5 \mathrm{~g}$ ), and elution with $n$-hexaneEtOAc (1: 1).

\subsection{Spectral Data of the Compounds}

$(1 S, 2 E, 4 R, 6 R, 7 E, 11 E)-2,7,11-C e m b r a t r i e n e-4,6-d i o l(1):$ white powder $(78 \mathrm{mg}, 0.06 \% \mathrm{w} / \mathrm{w}) ;[\alpha]_{\mathrm{D}}+291.1\left(\mathrm{CHCl}_{3}\right)$; IR $\left(\mathrm{CHCl}_{3}\right) v_{\max } \mathrm{cm}^{-1}: 3347(\mathrm{OH}), 2919(\mathrm{C}-\mathrm{H}), 1671(\mathrm{C}=\mathrm{C}), 1431,1373,1170,(\mathrm{C}-\mathrm{O}), 1119(\mathrm{C}-\mathrm{C}), 1096,1037,975,946$, 923, 755, 625. EIMS m/z (rel. int. \%): $306[\mathrm{M}]^{+} \mathrm{C}_{20} \mathrm{H}_{34} \mathrm{O}_{2}(0.1), 288$ [306- $\left.\mathrm{H}_{2} \mathrm{O}\right]$ (7), 273 [288- $\left.\mathrm{CH}_{3}\right](6), 260$ (14), 245 (21), 230 (4), 217 (13), 203 (10), 189 (15), 189 (6), 176 (19), 163 (18), 149 (11), 136 (32), 121 (44), 109 (58), 108 (51), 
105 (22), 95 (61), 93 (47), 81 (100), 67 (50), 43 (98) (Fig. 1A). ${ }^{1} \mathrm{H}$ NMR (500 MHz, CDCl $) \delta 5.39$ (d, $J=15.6 \mathrm{~Hz}, 1 \mathrm{H}$, H-3), 5.26 (br. d, $J=9.2 \mathrm{~Hz}, 1 \mathrm{H}, \mathrm{H}-7), 5.21$ (dd, $J=15.6,9.2 \mathrm{~Hz}, 1 \mathrm{H}, \mathrm{H}-2$ ), 4.99 (t, $J=5.3 \mathrm{~Hz}, 1 \mathrm{H}, \mathrm{H}-11$ ), 4.81 (ddd, $J$ $=9.2,9.2,1.4 \mathrm{~Hz}, 1 \mathrm{H}, \mathrm{H}-6), 2.05$ (dd, $J=14.1,1.4 \mathrm{~Hz}, 1 \mathrm{H}, \mathrm{H}-5 \mathrm{~b}), 1.92$ (dd, $J=12.0,3.7 \mathrm{~Hz}, 1 \mathrm{H}), 1.86$ (dd, $J=14.1$, $8.9 \mathrm{~Hz}, 1 \mathrm{H}, \mathrm{H}-5 \mathrm{a}), 1.70$ (d, $J=1.4 \mathrm{~Hz}, 3 \mathrm{H}, \mathrm{Me}-19), 1.50$ (s, 3H, Me-20), 1.39 (s, 3H, Me-18), $0.82(\mathrm{~d}, J=6.7 \mathrm{~Hz}, 3 \mathrm{H}$, Me-16), 0.79 (d, $J=6.7 \mathrm{~Hz}, 3 \mathrm{H}, \mathrm{Me}-17$ ) (Fig. 1C). ${ }^{13} \mathrm{C}$ NMR (125 MHz, CDCl $\left.{ }_{3}\right) \delta 136.47$ (C-8), 136.10 (C-3), 133.05 (C-12), 131.41 (C-7), 130.40 (C-2), 124.41 (C-11), 71.48 (C-4), 64.45 (C-6), 52.46 (C-5), 46.24 (C-1), 38.84 (C-9), 36.48 (C-13), 32.93 (C-15), 28.73 (C-18), 27.66 (C-14), 23.05 (C-10), 20.60 (C-17), 19.37 (C-16), 15.90 (C-19), 15.00 (C-20) (Fig. 1D).

$(1 S, 2 E, 4 S, 6 R, 7 E, 11 E)-2,7,11-C e m b r a t r i e n e-4,6-d i o l(2):$ white powder $(34 \mathrm{mg}, 0.025 \% \mathrm{w} / \mathrm{w}) ;[\alpha]_{\mathrm{D}}:+151.50$ $\left(\mathrm{CHCl}_{3}\right)$; IR $\left(\mathrm{CHCl}_{3}\right) v_{\max } \mathrm{cm}^{-1}: 3372(\mathrm{OH}), 2949.3,1670.0,1444,1186,1123,1082,1024,971,946.8,816,768,635$; EIMS $m / z$ (rel. int. \%): $306\left[\mathrm{M}^{+}\right] \mathrm{C}_{20} \mathrm{H}_{34} \mathrm{O}_{2}(0.98), 288$ [306- $\left.\mathrm{H}_{2} \mathrm{O}\right]$ (7), 273 [288- $\left.\mathrm{CH}_{3}\right](6), 260$ (14), 245 (21), 230 (4), 217 (13), 189 (15), 175 (12), 161 (18), 151 (30), 123 (43), 109 (58), 95 (61), 93 (46), 81 (100), 69 (50), 67 (34), 55 (52), 43 (98) (Fig. 1B). ${ }^{1} \mathrm{H}$ NMR (400 MHz, $\mathrm{CDCl}_{3}$ ) $\delta 5.39-5.20(\mathrm{~m}, 3 \mathrm{H}, \mathrm{H}-2, \mathrm{H}-3, \mathrm{H}-7), 5.03(\mathrm{t}, J=5.1 \mathrm{~Hz}, 1 \mathrm{H}, \mathrm{H}-11)$, 4.47 (ddd, $J=8.9,8.9,2.0 \mathrm{~Hz}, 1 \mathrm{H}, \mathrm{H}-6), 1.66$ (s, 3H, Me-19), 1.51 (s, 3H, Me-20), 1.34 (s, 3H, Me-18), 0.81 (d, $J=6.7$ $\mathrm{Hz}, 3 \mathrm{H}, \mathrm{Me}-16), 0.78$ (d, $J=6.7 \mathrm{~Hz}, 3 \mathrm{H}, \mathrm{Me}-17)$ Fig. (1E). ${ }^{13} \mathrm{C}$ NMR (100 MHz, CDCl $) \delta 137.55$ (C-3), $136.80(\mathrm{C}-8)$, 133.39 (C-12), 130.59 (C-7), 127.79 (C-2), 124.41 (C-11), 72.45 (C-4), 66.34 (C-6), 52.18 (C-5), 46.41 (C-1), 38.86 (C-9), 36.81(C-13), 33.00 (C-15), 30.12 (C-18), 27.95 (C-14), 23.33 (C-10), 20.65 (C-17), 19.34(C-16), 16.07 (C-19), 15.00 (C-20) (Fig. 1F).

\subsection{Cell Lines and Culture}

The following human cancer cell lines were purchased from the National Cell Bank of Iran, Pasteur Institute, Tehran, Iran: LS180 (human adenocarcinoma), MCF-7 (human breast adenocarcinoma) and MOLT-4 (human lymphoblastic leukemia) cells. The cells were cultured in RPMI 1640 medium supplemented with fetal bovine serum $(10 \% \mathrm{v} / \mathrm{v})$, penicillin (100 units/mL) and streptomycin $(100 \mu \mathrm{g} / \mathrm{ml})$. MOLT-4 cells were grown in suspension, while LS180 and MCF-7 cells were grown in monolayer cultures in humidified air containing $5 \% \mathrm{CO}_{2}$ at $37^{\circ} \mathrm{C}$.

\subsection{Cytotoxicity Assay}

The inhibitory effect of $\mathbf{1}$ and $\mathbf{2}$ against cancer cell growth was evaluated by the MTT reduction assay. This colorimetric assay is based on the conversion of the yellow 3-(4, 5-dimethylthiazol-2-yl)-2,5-diphenyl tetrazolium bromide (MTT) to the purple formazan by the action of mitochondrial enzyme succinate dehydrogenase in viable cells. Compounds 1 and 2 were dissolved in dimethylsulfoxide (DMSO) and diluted at least 400 times in growth medium before being incubated with cells. LS180, MCF-7 and MOLT-4 cells were seeded in 96-well plates at the densities of $50,000,30,000$ and 50,000 cells $/ \mathrm{mL}$ in $100 \mu \mathrm{L}$, respectively and incubated for $24 \mathrm{~h}$. Then, $50 \mathrm{~mL}$ of medium was replaced with fresh medium containing 3-4 different concentrations of the compounds. After $72 \mathrm{~h}$ of incubation, the medium of each well was replaced by fresh RPMI without phenol red containing $0.5 \mathrm{mg} / \mathrm{ml} \mathrm{MTT}$ and incubated at 37 ${ }^{\circ} \mathrm{C}$ for $4 \mathrm{~h}$. DMSO was used to solubilize the formed formazan crystals. The absorbance of different wells was measured at $570 \mathrm{~nm}$, with background correction at $655 \mathrm{~nm}$ using a microplate reader. The potency of cell growth inhibition for each compound was expressed as $\mathrm{IC}_{50}$ value, defined as the concentration that caused $50 \%$ of maximum inhibition of cell viability. $\mathrm{IC}_{50}$ values were calculated with software CurveExpert, version 1.3 for Windows.

\section{RESULTS AND DISCUSSION}

The structures of compounds 1 and 2 were elucidated using spectroscopic analysis, including ${ }^{1} \mathrm{H}$ NMR and APT ${ }^{13} \mathrm{C}$ NMR together with EIMS spectra and comparing them with those of reference compounds (Fig. 1A-F) [11, 13]. The stereochemistry of compound 1 was determined by X-ray crystallography (4), and later the absolute configuration of compound 2 was established by its ozonolysis followed by X-ray crystallography of the resulting degradation product [14] and at C-6, with chemical transformation to a related cembratriene-4,6,11-triol [15]. The carbon signals in the ${ }^{13} \mathrm{C}$ NMR spectra of both compounds $\mathbf{1}$ and $\mathbf{2}$ had identical or very near chemical shifts to those reported for the authentic samples in the literature [13]. The ${ }^{1} \mathrm{H}$ NMR spectra of the compounds were compared to those reported for compounds $\mathbf{1}$ and $\mathbf{2}$ and their related cembranoids $[11,13]$.

Inverting the stereochemistry at C-4 affected the chemical shifts of $\mathrm{C}-4$ ( $\delta 71.48$ to 72.45$)$, and had about 2 ppm changes in the chemical shifts at gamma positions: C-2 ( $\delta 130.40$ to 127.79$)$ and C-6 ( $\delta 64.45$ to 66.34$)$ in compound 1 
compared to those recorded for 2 , respectively. The epimerization at $\mathrm{C}-4$ also affected even more drastically the ${ }^{1} \mathrm{H}$ NMR spectral signals of the olefinic parts of compound 2. In the ${ }^{1} \mathrm{H}$ NMR spectrum of 1, the signals of $\mathrm{H}-2$, $\mathrm{H}-3$ and H-7 were well resolved and recorded at $\delta 5.21(\mathrm{dd}, J=15.6,9.2 \mathrm{~Hz}), 5.39(\mathrm{~d}, J=15.6 \mathrm{~Hz})$ and 5.26 (ddd, $J=9.2,9.2$, $1.4 \mathrm{~Hz}$ ), while in the ${ }^{1} \mathrm{H}$ NMR of 2 , these signals are presented as an unresolved multiplet at $\delta 5.39-5.20$ due to overlapping the signals in second-order interactions.

A

Abundance

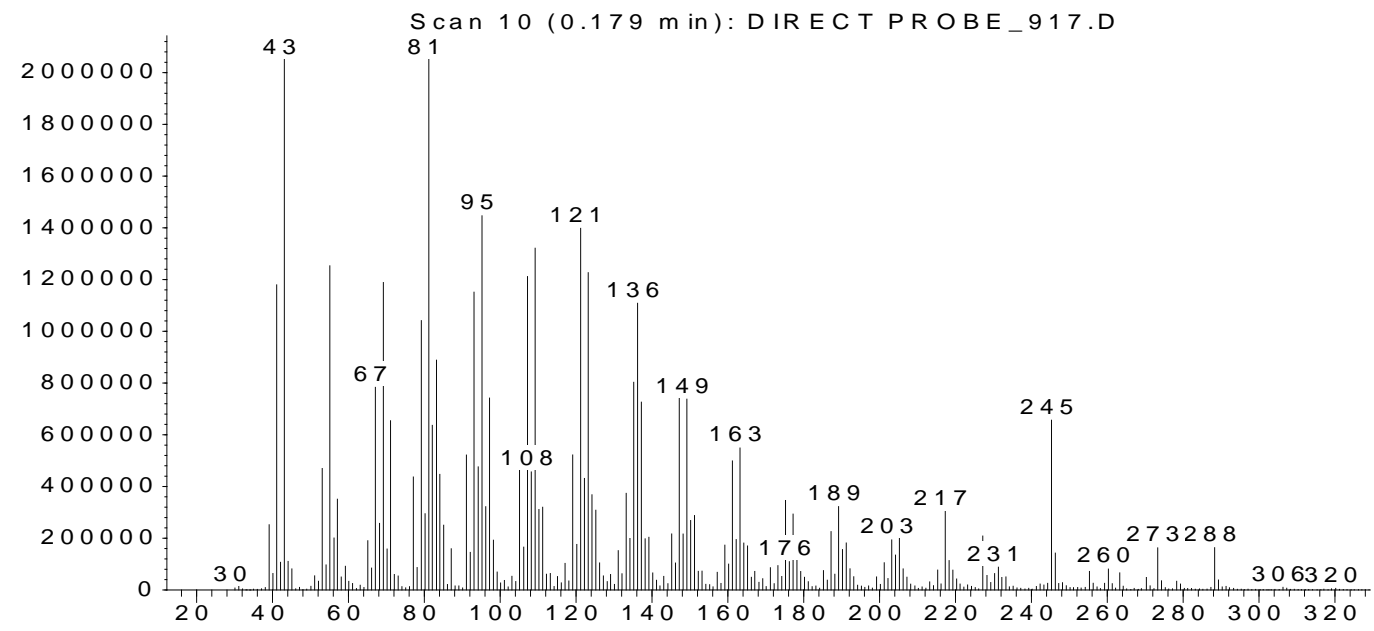

$\mathrm{m} / \mathrm{z}-->$

B

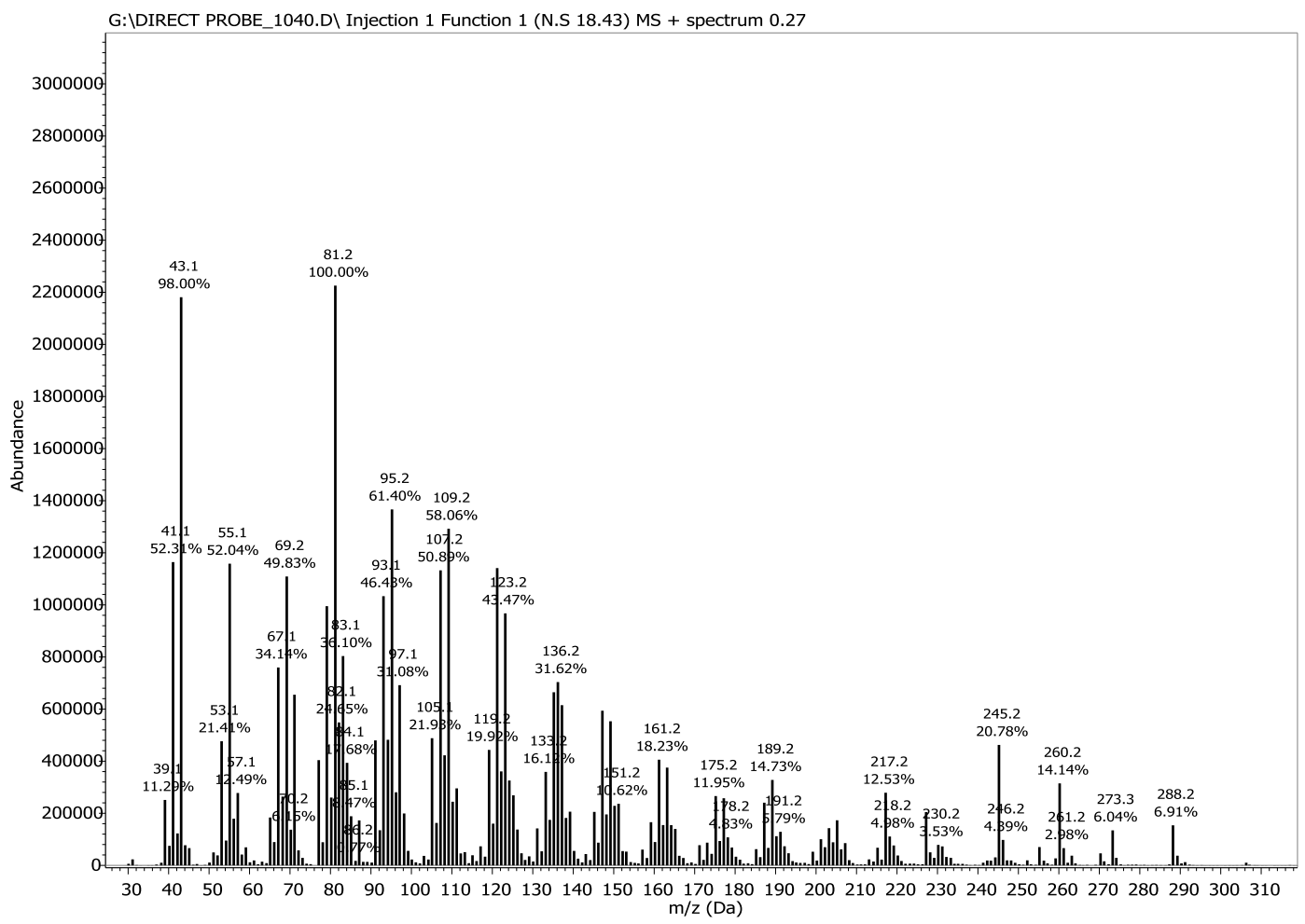

Fig. 1 contd..... 
C

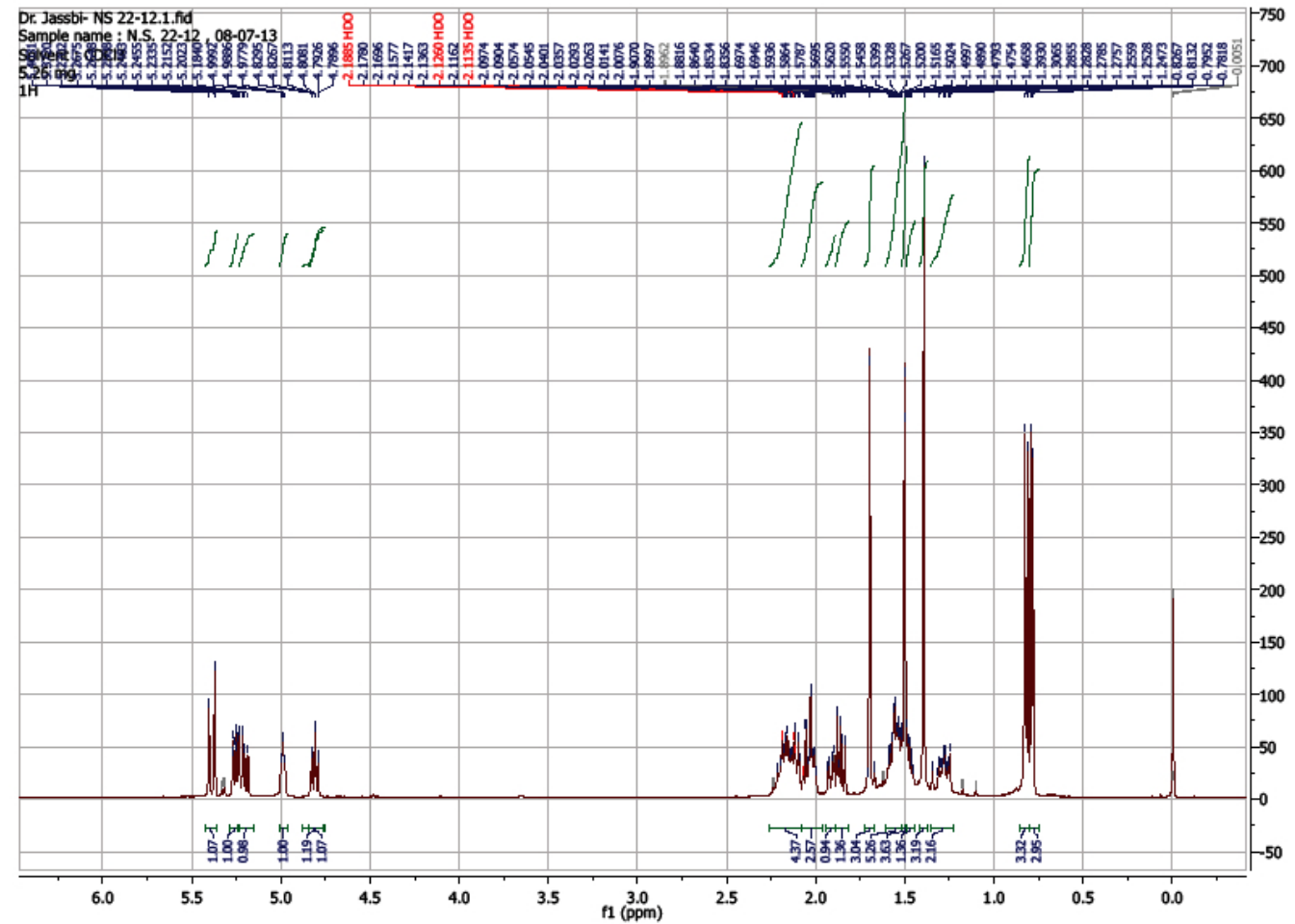

D

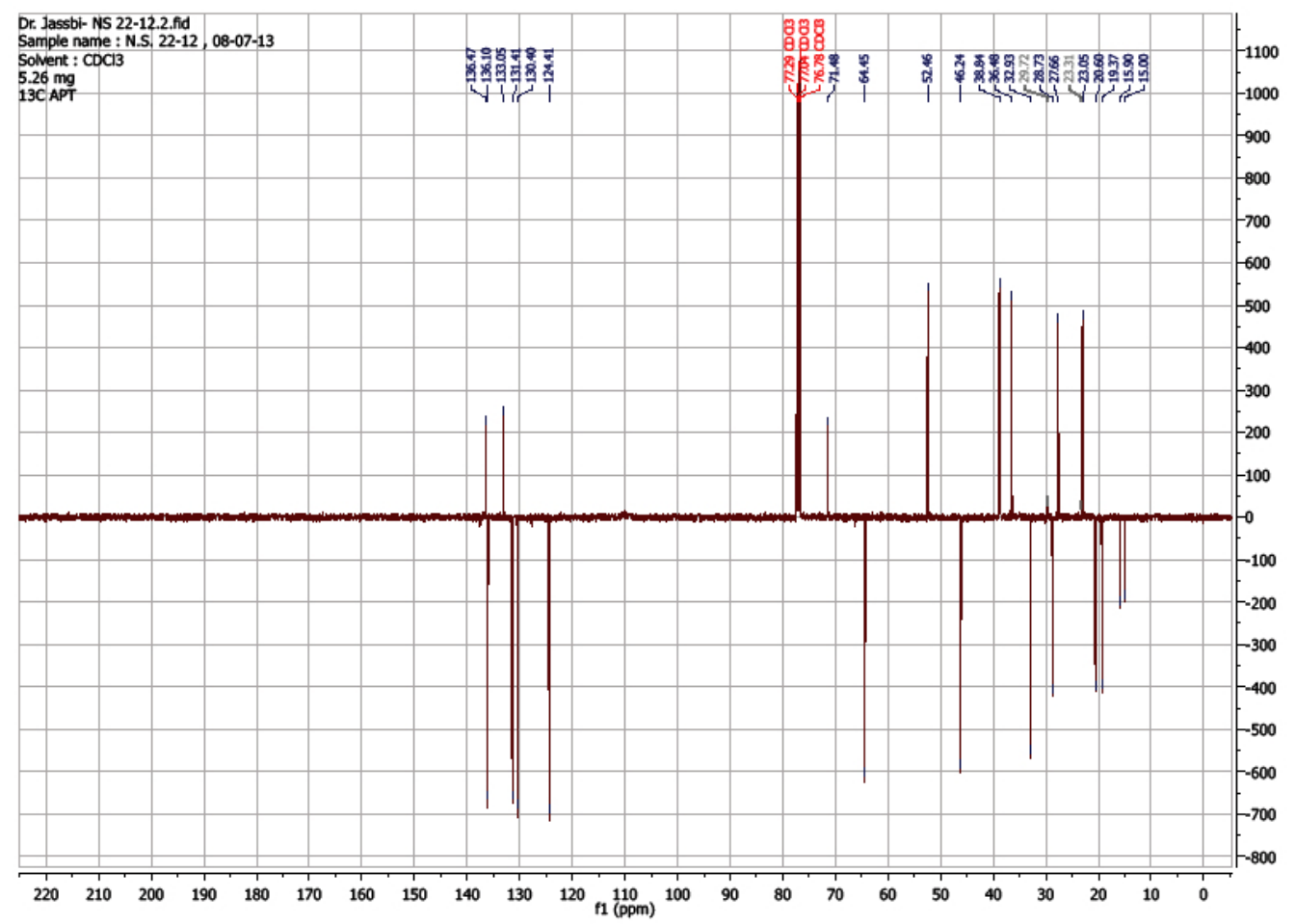

Fig. 1 contd..... 
E

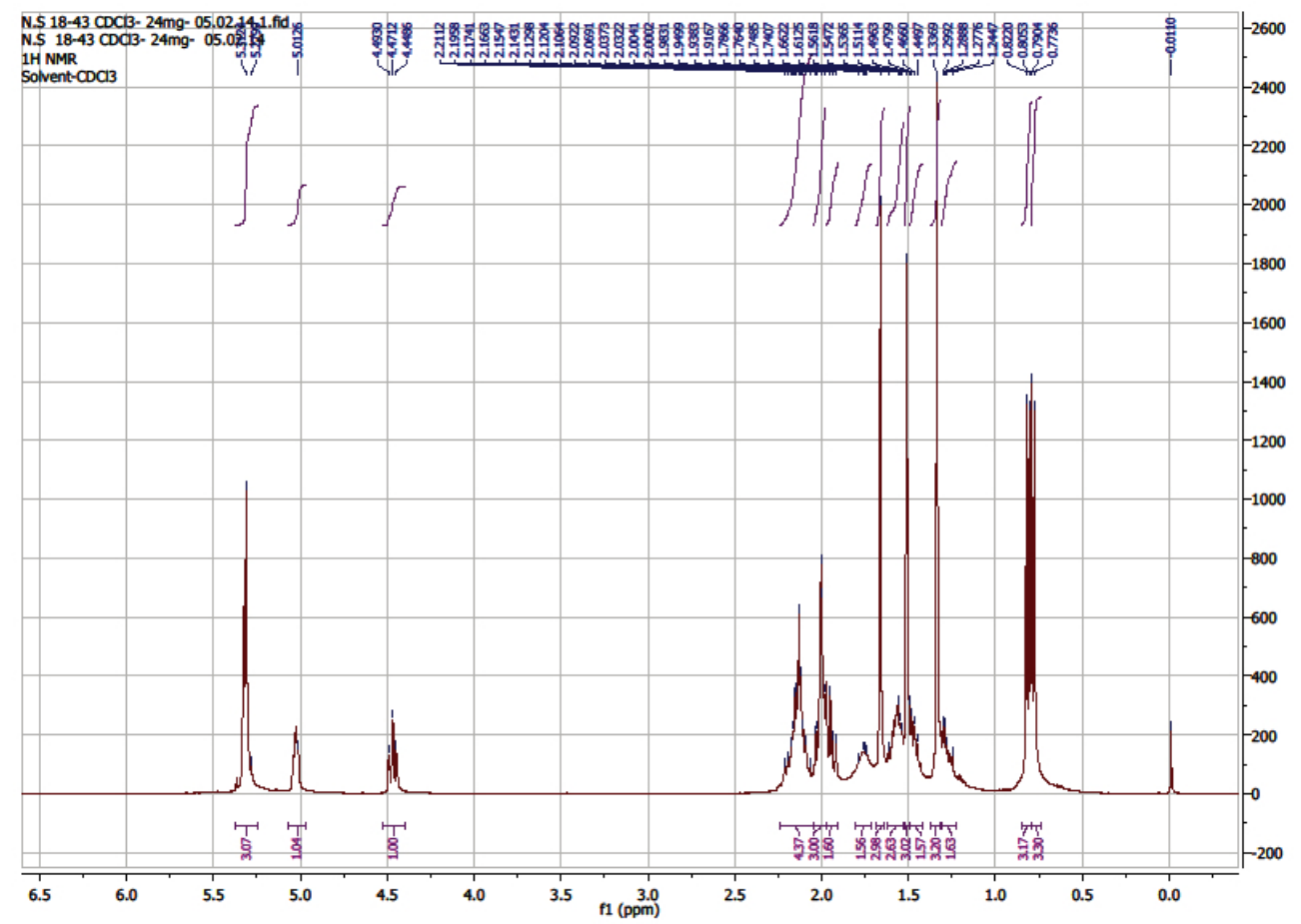

F

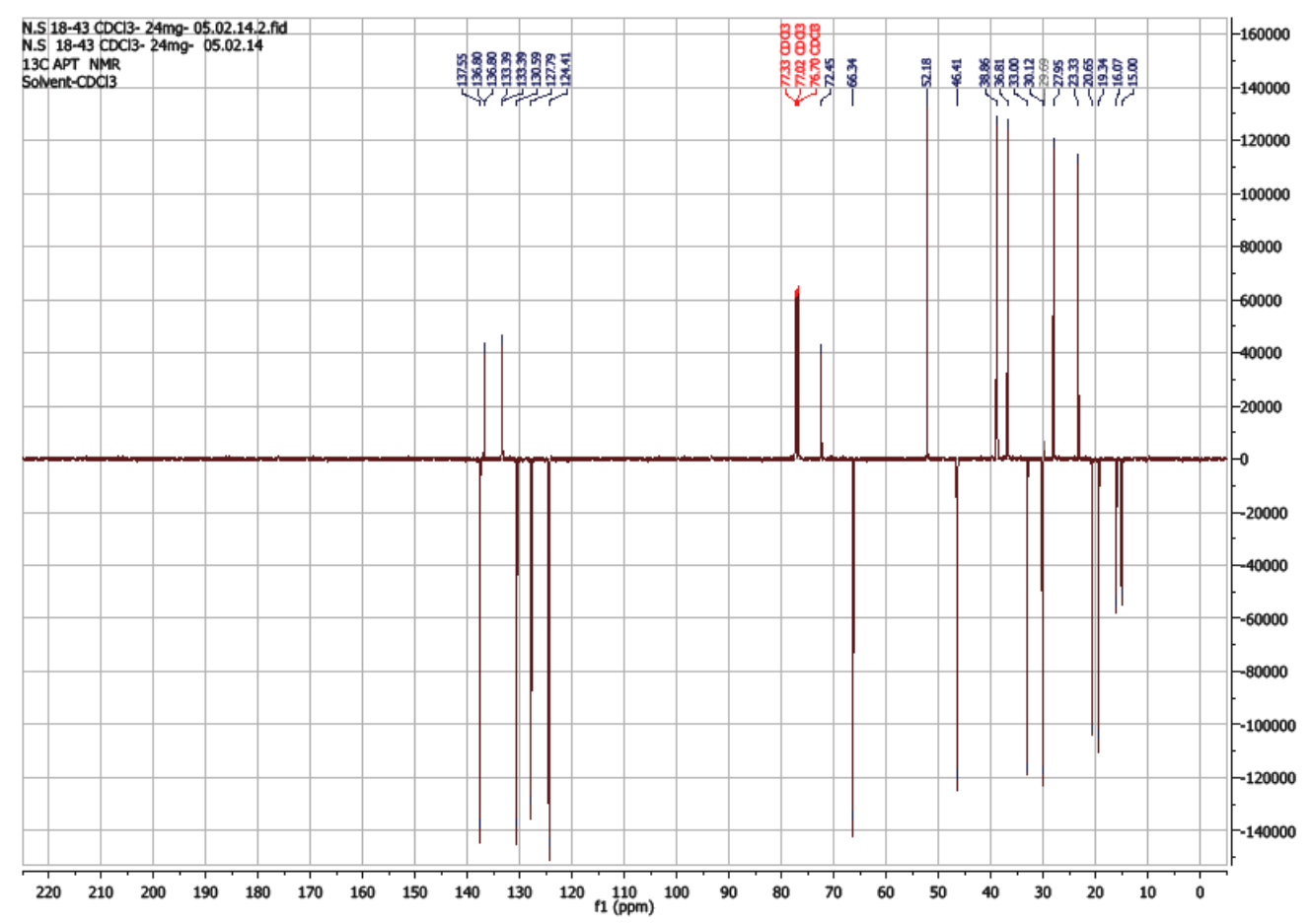

Fig. (1). EI-MS (A and B), ${ }^{1} \mathrm{H}$ NMR (C and E) and ${ }^{13} \mathrm{C}$ NMR (D and F; $500 \mathrm{MHz}$ in $\mathrm{CDCl}_{3}$ ) spectra of compounds 1 and 2 , respectively.

The cytotoxic potentials of compounds 1 and 2 were tested against three human cancer cell lines, LS180, MCF-7 and MOLT-4, and were presented as $\mathrm{IC}_{50} \mathrm{~s}$ in Table (1) in comparison to the standard anticancer agent cisplatin. The inhibitory effect of compounds $\mathbf{1}$ and $\mathbf{2}$ against tumor promotion has been previously reported. It has been shown that 
these compounds are able to inhibit the skin tumor promoting effect of 12-O-tetradecanoylphorbol-13-acetate (TPA) in mice [8]. The tumorigenisis inhibition of cembranoid diterepenoids against prostate cancer cell lines has also been reported for different derivatives of cembranoids $(1 S, 2 E, 4 S, 6 E, 8 S, 11 E)$-2,6,11-cembratriene-8-O-methyl-4,8-diol and the known $(1 S, 2 E, 4 R, 6 R, 7 E, 11 E)-2,7,11$-cembratriene-4-O-methyl-4,6-diol isolated from $N$. tabacum and their biotransformed, mostly oxidized products, by the action of two fungal strains: Cunninghamella NRRL 5695 and Mucor ramannianus ATCC 9628 [9]. Compound 1 was converted into its C-6 hydroxyl esters with different carbamate functionalities and also to different hydroxylation reaction biocatalyzed by symbiotic Bacillus species isolated from a Red sea marine sponge [11]. Compound 1 and its derivatives were tested on highly invasive prostate cancer cell lines and a SAR conclusion indicated their high potential against cancer cell lines due to the polar substitution on C-6 hydroxy group [11].

The semisynthetic products and a secocembranoid diterpenoid resulted from the reaction of compound $\mathbf{1}$ with different halogenated carbamic acids and also reactions catalyzed in the presence of marine Bacillus species and $M$. ramannianus ATCC 9628 and C. elegans showed antiproliferative activity against highly malignant + SA mammary epithelial cells with an $\mathrm{IC}_{50}$ range of $15-30 \mu \mathrm{M}[10]$.

The relatively good cytotoxic activity of compounds $\mathbf{1}$ and $\mathbf{2}$ (Table $\mathbf{1}$ ) in comparison to the standard anticancer agent cisplatin against the tested cancer cell lines in the present study is compatible with the previous reports.

Table 1. Cytotoxic activity of compounds 1 and 2 against human cancer lines determined by MTT reduction assay.

\begin{tabular}{|c|c|c|c|}
\hline \multirow{2}{*}{ Sample } & \multicolumn{3}{|c|}{ IC $_{\mathbf{5 0}}(\boldsymbol{\mu M})$} \\
\cline { 2 - 4 } & LS-180 & MCF-7 & MOLT-4 \\
\hline Compound 1 & $42.6 \pm 3.2$ & $44.0 \pm 6.4$ & $39.4 \pm 4.8$ \\
\hline Compound 2 & $42.8 \pm 2.1$ & $35.2 \pm 3.6$ & $28.4 \pm 3.7$ \\
\hline Cisplatin & $5.9 \pm 2.4$ & $12.6 \pm 5.8$ & $3.1 \pm 0.8$ \\
\hline
\end{tabular}

The results are presented as mean \pm S.E.M. of 3-4 experiments.

\section{ETHICS APPROVAL AND CONSENT TO PARTICIPATE}

Not applicable.

\section{CONSENT FOR PUBLICATION}

Not applicable.

\section{CONFLICT OF INTEREST}

The authors declare no conflict of interest, financial or otherwise.

\section{ACKNOWLEDGEMENTS}

The authors are thankful to financial supports of Shiraz University of Medical Sciences, the University of Yasooj, Iran, and Alexander von Humboldt Foundation (grant number: 3.4 - IRN/1101775).

\section{REFERENCES}

[1] Gray JC, Kung SD, Wildman SG, Sheen SJ. Origin of Nicotiana tabacum L detected by polypeptide composition of Fraction I protein. Nature 1974; 252(5480): 226-7.

[http://dx.doi.org/10.1038/252226a0] [PMID: 4421263]

[2] Wallin I, Narbonne C, Wahlberg I, Nishida T, Enzell CR. Two new acyclic diterpenoids from Nicotiana sylvestris. Acta Chem Scand B 1980; 34: 391-6.

[http://dx.doi.org/10.3891/acta.chem.scand.34b-0391]

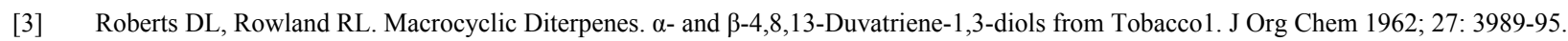
[http://dx.doi.org/10.1021/jo01058a056]

[4] Springer JP, Clardy J, Cox RH, Cutler HG, Cole RJ. The structure of a new type of plant growth inhibitor extracted from immature tobacco leaves. Tetrahedron Lett 1975; 16: 2737-40. [http://dx.doi.org/10.1016/S0040-4039(00)75227-0]

[5] Wahlberg I, Enzell C. Tobacco cembranoids. Beitr Tabakforsch Int 1984; 12: 93-104. [http://dx.doi.org/10.2478/cttr-2013-0530]

[6] Olsson E, Holth A, Kumlin E, Bohlin L, Wahlberg I. Structure-related inhibiting activity of some tobacco cembranoids on the prostaglandin 
synthesis in vitro. Planta Med 1993; 59(4): 293-5.

[http://dx.doi.org/10.1055/s-2006-959684] [PMID: 8372141]

[7] Ferchmin PA, Lukas RJ, Hann RM, et al. Tobacco cembranoids block behavioral sensitization to nicotine and inhibit neuronal acetylcholine receptor function. J Neurosci Res 2001; 64(1): 18-25. [http://dx.doi.org/10.1002/jnr.1049] [PMID: 11276047]

[8] Saito Y, Takizawa H, Konishi S, Yoshida D, Mizusaki S. Identification of cembratriene-4,6-diol as antitumor-promoting agent from cigarette smoke condensate. Carcinogenesis 1985; 6(8): 1189-94. [http://dx.doi.org/10.1093/carcin/6.8.1189] [PMID: 2990757]

[9] Baraka HN, Khanfar MA, Williams JC, El-Giar EM, El Sayed KA. Bioactive natural, biocatalytic, and semisynthetic tobacco cembranoids. Planta Med 2011; 77(5): 467-76

[http://dx.doi.org/10.1055/s-0030-1250478] [PMID: 21049399]

[10] El Sayed KA, Laphookhieo S, Yousaf M, et al. Semisynthetic and biotransformation studies of (1S,2E,4S,6R,7E,11E)-2,7,11cembratriene-4,6-diol. J Nat Prod 2008; 71(1): 117-22. [http://dx.doi.org/10.1021/np0704351] [PMID: 18177013]

[11] El Sayed KA, Laphookhieo S, Baraka HN, et al. Biocatalytic and semisynthetic optimization of the anti-invasive tobacco (1S,2E,4R,6R,7E,11E)-2,7, 11-cembratriene-4,6-diol. Bioorg Med Chem 2008; 16(6): 2886-93. [http://dx.doi.org/10.1016/j.bmc.2007.12.056] [PMID: 18222089]

[12] Jassbi AR, Gase K, Hettenhausen C, Schmidt A, Baldwin IT. Silencing geranylgeranyl diphosphate synthase in Nicotiana attenuata dramatically impairs resistance to tobacco hornworm. Plant Physiol 2008; 146(3): 974-86. [http://dx.doi.org/10.1104/pp.107.108811] [PMID: 17965175]

[13] Wahlberg I, Arndt R, Wallin I, Vogt C, Nishida T, Enzell CR. Tobacco Chemistry. 59. Six New Cembratrienetriols from Tobacco. Acta Chem Scand B 1984; 38: 21-30 [http://dx.doi.org/10.3891/acta.chem.scand.38b-0021]

[14] Aasen AJ, Junker N, Enzell CR, Berg J-E, Pilotti A-M. Tobacco chemistry 36. Absolute configuration of tobacco thunberganoids. Tetrahedron Lett 1975; 16: 2607-10.

[http://dx.doi.org/10.1016/S0040-4039(00)75193-8]

[15] Wahlberg I, Wallin I, Narbonne C, Nishida T, Enzell CR, Berg J. Tobacco chemistry. 55. Three new cembranoids from Greek tobacco. The stereochemistry of (1S, 2E, 4S, 6R, 7E, 11E)-2, 7, 11-cembratriene-4, 6-diol. Acta Chem Scand B 1982; $36: 3$.

(C) 2017 Jassbi et al.

This is an open access article distributed under the terms of the Creative Commons Attribution 4.0 International Public License (CC-BY 4.0), a copy of which is available at: https://creativecommons.org/licenses/by/4.0/legalcode. This license permits unrestricted use, distribution, and reproduction in any medium, provided the original author and source are credited. 